\title{
Beneficial Role of 1-Methylcyclopropene for Cut Lupinus havardii Racemes Exposed to Ethephon
}

\author{
Mario Valenzuela-Vázquez ${ }^{1}$ \\ Universidad Autónoma de Ciudad Juárez, Anillo Envolvente del Pronaf y \\ Estocolmo s/n, Col. Zona Pronaf. C.P. 32300. A.P. 1595-D. Cd. Juárez, \\ Chihuahua, México
}

\author{
Geno A. Picchioni \\ Department of Plant and Environmental Sciences, New Mexico State \\ University, Las Cruces, NM 88003
}

\section{Leigh W. Murray \\ University Statistics Center, New Mexico State University, Las Cruces, NM 88003}

\section{Wayne A. Mackay \\ Texas A \& M University Research and Extension Center, 17360 Coit Road, Dallas, TX 75252}

Additional index words. Big Bend bluebonnet, ethylene, specialty cut flowers, senescence, desiccation, bud opening, vase life, abscission, leakage

\begin{abstract}
The raceme of Lupinus havardii Wats. (Big Bend bluebonnet) is a new greenhouse specialty cut flower, but postharvest life is limited by ethylene sensitivity. The authors studied the effects of $160 \mathrm{~nL} \cdot \mathrm{L}^{-1} 1$-methylcyclopropene (1-MCP) with 0 to 6 days exposure to a 50- $\mu_{M}$ vase solution of ethephon [(2-chloroethyl) phosphonic acid, CEPA] on raceme postharvest quality indices and mature flower cell membrane permeability. With no CEPA, 1-MCP delayed postharvest losses in fresh weight and mature flower retention, and extended vase life longevity (VLL) by 1 to 4 days relative to a non-1-MCP control. With 2 days or more of CEPA, 1-MCP deferred raceme fresh weight loss and the abscission of both mature and newly opened flowers from 3 days to 5 days. There was a relatively strong protective effect of 1-MCP on raceme fresh weight, flower retention, and newly opening flowers in the presence of CEPA compared with the absence of CEPA. The greatest raceme VLL (7.2 days) was obtained for 1-MCP-treated racemes that did not receive CEPA in the vase. Although VLL was reduced by CEPA, VLL was consistently greater (by $\approx 2$ days) after $1-M C P$ treatment relative to no 1-MCP treatment and irrespective of CEPA's duration. As expected, electrolyte leakage increased with individual flower development and between 1 day and 6 days in the vase. Unexpectedly, however, the 5-day postharvest increase in leakage was intensified by 1MCP treatment if the racemes were exposed to 1 hour of CEPA in the vase solution. Electrical conductivity measurements suggested that, in the latter treatment $(+1-\mathrm{MCP}$, +CEPA), increased levels of diffusible electrolytes that had yet to be exported to the expanding apical meristem (delayed raceme development) contributed to the higher leakage. Results also demonstrate good potential for quality maintenance of $L$. havardii racemes by using 1-MCP, and that in addition to flower retention, raceme fresh weight and flower opening should be considered in developing VLL criteria for this new specialty crop.
\end{abstract}

Lupinus havardii (Big Bend bluebonnet) is a relatively new greenhouse-grown specialty cut flower (Davis et al., 1994; Mackay

\footnotetext{
Received for publication 30 Mar. 2006. Accepted for publication 22 July 2006.

This study was supported by the Fred C. Gloeckner Foundation (Harrison, N.Y.), the New Mexico Agricultural Experiment Station, Consejo Nacional de Ciencia y Tecnología (CONACYT, México), and Instituto Nacional de Investigaciones Forestales, Agrícolas y Pecuarias (INIFAP, México).

${ }^{1}$ To whom reprint requests should be addressed; e-mail mvalenzu@uacj.mx
}

tion of raceme ethylene synthesis (in the oldest, basal flowers) occurs as early as 5 to $9 \mathrm{~d}$ before the raceme reaches harvestable size and is brought to the postharvest environment (Mackay et al., 1999; Vasquez, 1998). After harvest and placement in a vase for 4 to $6 \mathrm{~d}$ at $21{ }^{\circ} \mathrm{C}$ in air and with no preconditioning treatment, desiccation and abscission of flowers at the inflorescence base are observed, by which time the functional vase life has ended (Davis et al., 1994; Mackay et al., 1999; Sankhla et al., 1999). Concurrently, expansion of the apical meristematic sink results in the appearance of newly opened flowers that typically represent a $40 \%$ to $50 \%$ increase in the total number of open flowers originally present at harvest. Thus, vase life of cut L. havardii racemes is a spatially and sequentially organized process, with the most advanced developmental stage at the base, progressing to the least developmentally advanced stage at the apex.

Postharvest application of the ethylene action inhibitor 1-methylcyclopropene (1MCP) is an environmentally safe treatment in delaying senescence of ethylene-sensitive cut flowers, such as carnation, stock, waxflower, snapdragon, and Gypsophila (Celikel and Reid, 2002; Newman et al., 1998; Serek et al., 1995a, b; Sisler et al., 1996). Limited data support use of 1-MCP for prolonging vase life of cut L. havardii (Picchioni et al., 2002; Sankhla et al., 2001). However, the effects of 1-MCP on delaying the expression of specific senescence-related traits along the cut axis of $L$. havardii are not adequately known. Therefore, the objectives of this study were to evaluate the influence of 1-MCP postharvest treatment on cut L. havardii raceme fresh weight and flower retention, apical flower opening, electrolyte leakage, and vase life longevity. We held racemes in vase solutions with or without ethephon [(2, chloroethyl) phosphonic acid, or CEPA] to investigate the ability of 1-MCP to counteract the influence of an exogenous ethylene source (ethylene released from CEPA) on the aforementioned variables.

\section{Materials and Methods}

Crop cultivation, harvest, and initial handling. Culture of L. havardii 'Texas Sapphire' plants was carried out under greenhouse conditions described previously (Picchioni et al., 2002). Inflorescences (racemes) were harvested at 112,130 , and 138 $\mathrm{d}$ after transplanting and between 0700 and 0900 HR. Cut racemes had yet to abscise flowers or express senescence-related desiccation or darkening of the standard petal (Dracup and Kirby, 1996), and were of the marketable size of 40 to $55 \mathrm{~cm}$ in length while supporting a minimum of 20 to 30 fully opened flowers (Mackay and Davis, 1998). A flower was considered fully open when the blue standard petal with yellow banner was fully reflexed and folded at its margins.

Immediately after cutting, initial fresh weight and fully opened flower number per raceme were recorded, and the proximal 

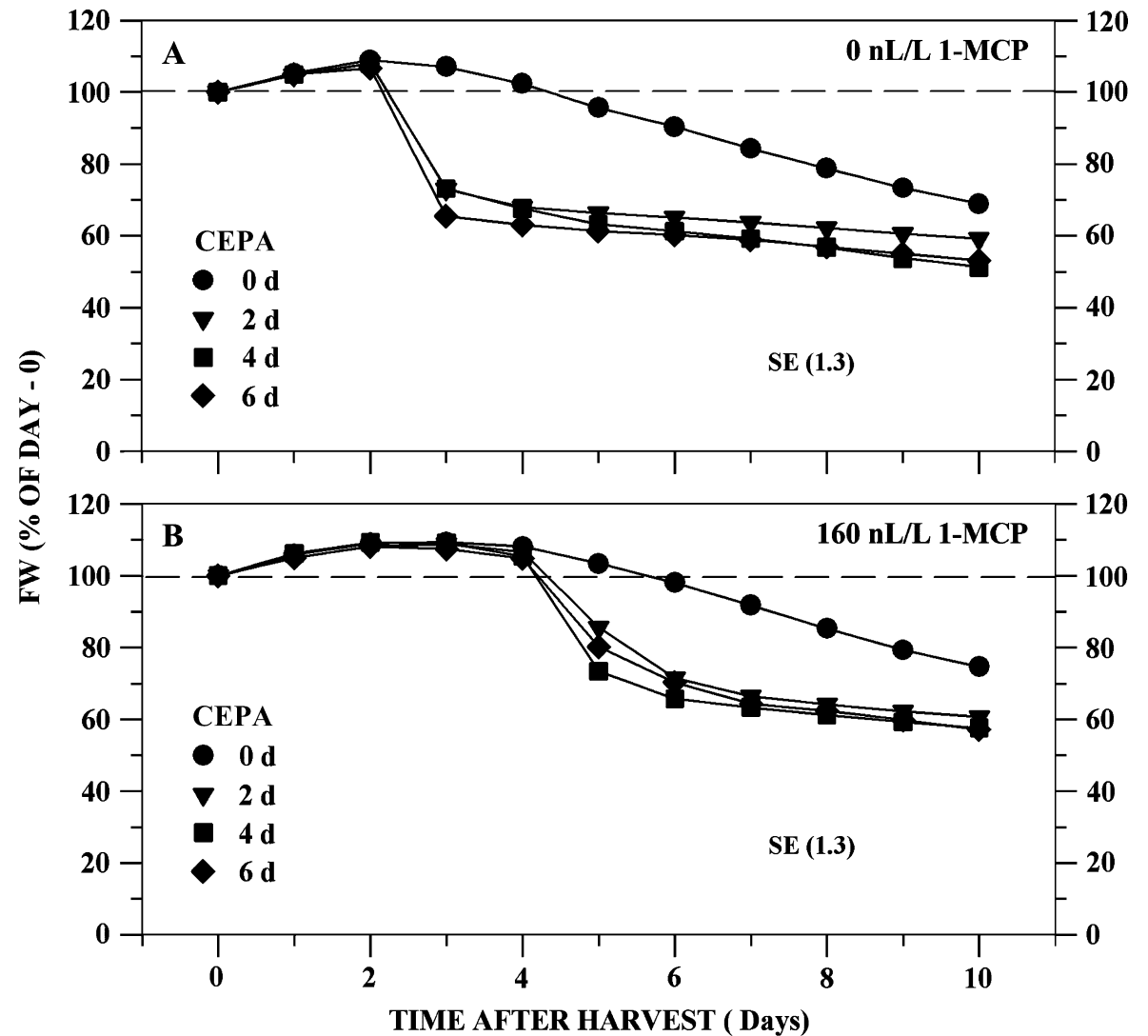

Fig. 1. (A, B) Total fresh weight (FW) of cut 'Texas Sapphire' racemes expressed as percentage at harvest (day 0), without 1-methylcyclopropene (1-MCP) (A) or after postharvest 1-MCP treatment at $160 \mathrm{~nL} \cdot \mathrm{L}^{-1}(\mathbf{B})$, and further 2, chloroethyl phosphonic acid (CEPA) exposure $(50 \mu \mathrm{M})$ for $0,2,4$, or $6 \mathrm{~d}$ in the vase solution. Each point is the average of 10 single-raceme observations (combined data of two experiments). The $F$ tests for main effects of 1-MCP, CEPA, and days in the vase were significant at $P \leq 0.01$. The pooled $\mathrm{SE}$ is from the analysis of variance.

$12-\mathrm{cm}$ ends of the peduncles were placed in vases (one raceme per vase replication) containing $200 \mathrm{~mL}$ deionized water. Two small dots of water-based ink were placed on the rachis of each inflorescence, one at the uppermost fully opened flower, and another to bisect the upper half and lower half of fully opened flowers. The dots facilitated counting of the number of newly opened flowers per raceme (NNOF) during vase observation, and flower sampling for leakage experiments (described later). Racemes were then placed in an adjacent headhouse at $\approx 20{ }^{\circ} \mathrm{C}$ to await postharvest treatments with 1-MCP and CEPA.

Postharvest 1-MCP and CEPA, and raceme fresh weight, flower retention, expansion, and vase life longevity (Expts. 1 and 2). Two identical experiments were conducted to investigate postharvest performance with or without 1-MCP and CEPA. For 1-MCP treatment, we followed the procedure of Celikel and Reid (2002) with a Plexiglas chamber volume at $0.35 \mathrm{~m}^{3}$ and holding 20 racemes. For the 1-MCP-treated racemes, the 1-MCP concentration was 160 $\mathrm{nL} \cdot \mathrm{L}^{-1}$. The $1-\mathrm{MCP}$ treatment began $12 \mathrm{~h}$ after harvest and lasted $12 \mathrm{~h}$ at $20^{\circ} \mathrm{C}$ (ending $24 \mathrm{~h}$ after harvest). The source of $1-\mathrm{MCP}$ was EthylBloc $(0.14 \%$ w:w 1-MCP; Floralife, Inc., Walterboro, S.C.). Immediately after 1-MCP treatment, racemes were taken to the laboratory for CEPA treatment and $10 \mathrm{~d}$ of postharvest evaluation at $24 \pm 1{ }^{\circ} \mathrm{C}, 50 \%$ to $60 \%$ relative humidity, and a $24-\mathrm{h}$ photoperiod under $25 \mu \mathrm{mol} \cdot \mathrm{m}^{-2} \cdot \mathrm{s}^{-1} P P F$ (coolwhite fluorescent lamps).

We applied CEPA to the vase solution to simulate postharvest exposure of racemes to exogenous ethylene. In our previous and ongoing research, the CEPA application method has served as a rapid screening tool for identifying and developing $L$. havardii genotypes with reduced levels of ethylenedependent flower abscission and senescence (example in Sankhla et al., 2001). In the current study, CEPA treatment was initiated $24 \mathrm{~h}$ after harvest (following the 12-h 1-MCP treatment). The vase solutions included a control (200 $\mathrm{mL}$ deionized water without CEPA) or $200 \mathrm{~mL}$ of $50 \mu \mathrm{M}$ CEPA in deionized water for 2, 4, or $6 \mathrm{~d}$. All four CEPA treatments were established with or without previous 1-MCP exposure, thus comprising eight total postharvest treatments. The source of CEPA (ethephon) was Florel fruit eliminator [3.9\% w:v (2-chloroethyl) phosphonic acid; Lawn and Garden Products, Inc., Fresno, Calif.]. After the 2, 4, or $6 \mathrm{~d}$ of CEPA treatment, racemes were transferred to individual vases containing $200 \mathrm{~mL}$ deionized water for further observation.

Daily measurements included raceme fresh weight, mature flower retention, and raceme expansion, expressed as NNOF at the apex. The beginning of vase life was defined as the harvest day (day 0), at which time fresh weight and flower retention were designated as $100 \%$. For each raceme, fresh weight and flower retention during vase life $(1-10 \mathrm{~d})$ were expressed as percentages of their day 0 values, whereas NNOF was recorded as an absolute number. Vase life longevity (VLL) was defined as the average time (days) required for $\geq 50 \%$ of mature flowers (open at harvest) to abscise or to express withering.

Postharvest 1-MCP and CEPA, and membrane permeability (Expt. 3). A third experiment evaluated the effects of postharvest 1-MCP and CEPA on membrane permeability of mature flowers, expressed as electrolyte leakage. Methods were identical to those in Expts. 1 and 2, except that two racemes were used per vase replication, and CEPA was applied for either $0 \mathrm{~h}$ or $1 \mathrm{~h}$. There were two vases (each with two racemes) for each of the $2(1-\mathrm{MCP}) \times 2(\mathrm{CEPA}) \times 2$ (vase life days) treatment combinations. After harvest, racemes were taken to the laboratory and placed in deionized water vases under the laboratory conditions. For both 1 and 6-d leakage assessments, 10 mature flowers (fully expanded at the time of harvest) from the lower and upper halves of each raceme replicate pair were excised (to exclude the pedicel), and were placed in separate flasks containing $75 \mathrm{~mL}$ deionized water $(20$ total flowers per raceme position per replication). Any abscised flowers were excluded. The flasks were gently swirled and after $24 \mathrm{~h}$, the electrical conductivity (EC) of the decanted solution was measured. At this time, the flowers (without solution) were frozen in liquid $\mathrm{N}_{2}$, and the decanted solution was returned to its respective flask containing the frozen flowers. After an additional $24 \mathrm{~h}$ in the efflux solution, a final EC measurement was obtained, and the relative leakage ratio (RLR) was then calculated as EC before freezing divided by EC after freezing. The EC readings were first adjusted by subtracting the background EC of the deionized water $\left(10 \mu \mathrm{S} \cdot \mathrm{cm}^{-1}\right)$.

\section{Statistical analysis}

All experiments were set up with five replications per treatment combination. A replication (experimental unit) was one raceme in a vase for Expts. 1 and 2, and a pair of racemes per vase for Expt. 3. Response variables analyzed by analysis of variance (ANOVA) included VLL and the daily fresh weight, flower retention, and NNOF for Expts. 1 and 2, and RLR for Expt. 3.

Experiments 1 and 2 were first analyzed separately, as a split plot with a completely randomized design on the whole plot and whole-plot treatments in a $2(1-\mathrm{MCP}) \times 4$ (CEPA exposure duration) factorial. Number of days in vase was the split-plot factor. ANOVA was performed for each experiment using the GLM procedure of the Statistical Analysis System (SAS Institute, 1990). Similar results were obtained for each experiment, thus data were processed as a pooled 

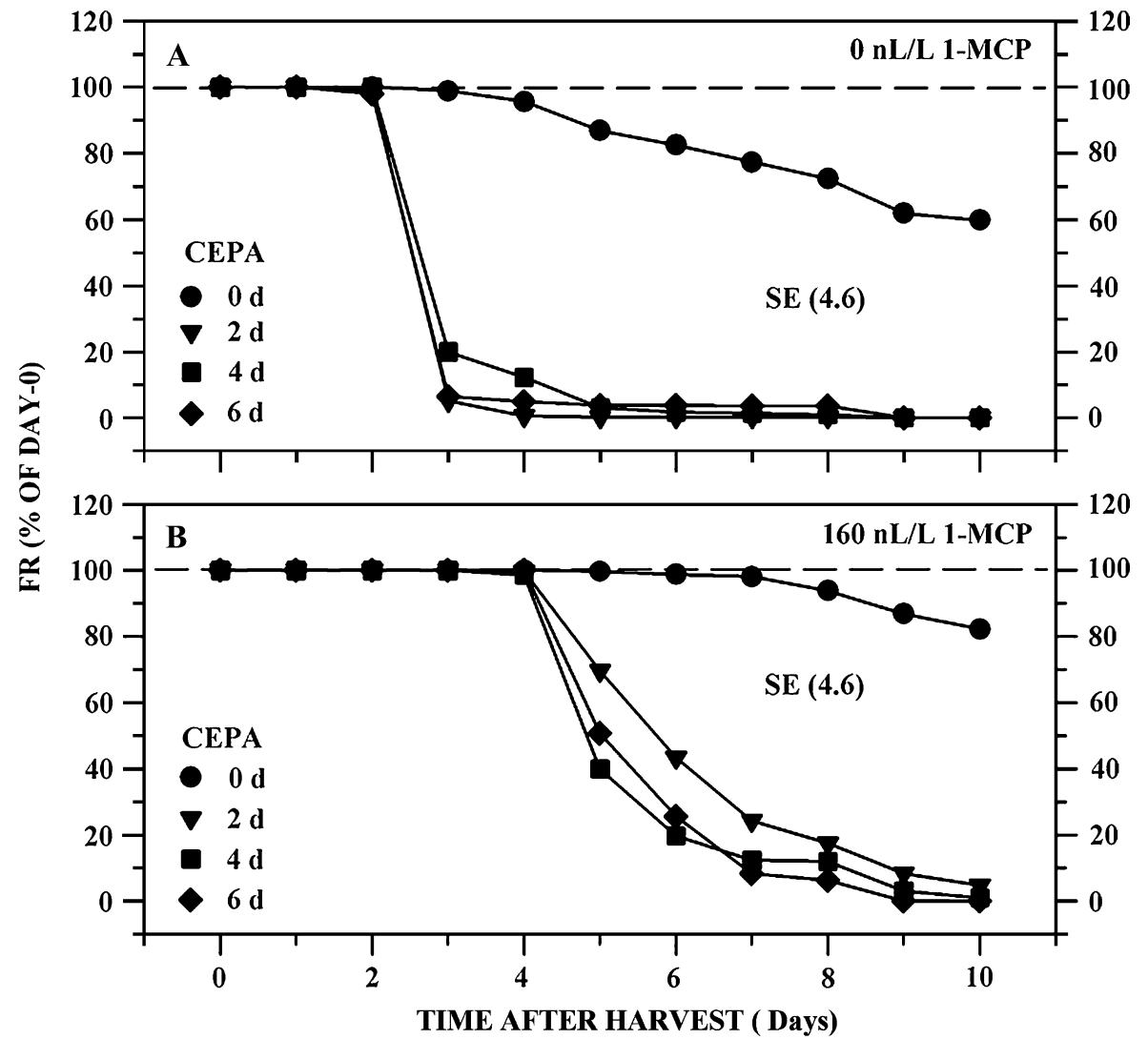

Fig. 2. (A, B) Mature flower retention (FR) on cut 'Texas Sapphire' racemes expressed as percentage at harvest (day 0), without 1-methylcyclopropene (1-MCP) (A) or after postharvest 1-MCP treatment at $160 \mathrm{~nL} \cdot \mathrm{L}^{-1}(\mathbf{B})$, and further 2, chloroethyl phosphonic acid (CEPA) exposure $(50 \mu \mathrm{M})$ for $0,2,4$, or $6 \mathrm{~d}$ in the vase solution. Each point is the average of 10 single-raceme observations (combined data of two experiments). The $F$ tests for main effects of 1-MCP, CEPA, and days in the vase were significant at $P \leq 0.01$. The pooled SE is from the analysis of variance.

ANOVA and performed using the MIXED procedure of SAS (SAS Institute, 1990). The pooled analysis was similar to the separate analyses, except that the whole-plot treatments were in a $2(1-\mathrm{MCP}) \times 4$ (CEPA exposure duration) $\times 2$ (experiment) factorial. Linear and quadratic polynomial contrasts were performed as posthoc tests for the CEPA main effect when it did not interact with 1-MCP. Mean and SE were also calculated.

For Expt. 3, separate ANOVAS were performed for each fully opened flower position (lower and upper). Data were analyzed as a $2(1-\mathrm{MCP}) \times 2$ (CEPA exposure duration) $\times 2$ (days in vase) factorial in a completely randomized design using the SAS GLM procedure (SAS Institute, 1990). Mean and SE were also calculated.

\section{Results}

Raceme fresh weight, mature flower retention, flower expansion (NNOF), and vase life longevity (Expts. 1 and 2). For all responses, there were some significant interactions involving the experiment factor, but the basic patterns were similar (even though statistically significant) across the two experiments. Therefore, we report only those results averaging over the two experiments. For the pooled analysis of Expts. 1 and 2, there were significant three-way 1-MCP $\times$ CEPA $\times$ days in vase interactions for fresh weight, flower retention, and NNOF (Figs. 1$3)$. There were also significant two-way interactions for $1-\mathrm{MCP} \times$ days in vase, 1 -MCP $\times$ CEPA, and CEPA $\times$ days in vase, as well as significant main effects. We focus on the three-way interaction $1-\mathrm{MCP} \times \mathrm{CEPA}$ $\times$ days in vase, because it provides complete information about the relationship between 1-MCP and CEPA over time. In addition, we report the $1-\mathrm{MCP} \times$ days in vase interaction (averaging over CEPA level) for a practical assessment of the effect of 1-MCP on vase life when ethylene exposure cannot be controlled or predicted (e.g., shipping, transporting, and storing).

The three-way 1 -MCP $\times$ CEPA $\times$ days in vase interaction is apparent in Figs. 1 through 3. Without 1-MCP or CEPA treatment, a net fresh weight gain of $2 \%$ to $9 \%$ was observed during the first $4 \mathrm{~d}$ of vase life (Fig. 1A). Thereafter, these racemes steadily lost fresh weight so that after $10 \mathrm{~d}$ of vase life, they had retained an average of $69 \%$ of their original fresh weight recorded at harvest (day 0). If the non-1-MCP-treated racemes stood in $50 \mu \mathrm{M}$ CEPA for 2 to $6 \mathrm{~d}$, their fresh weight decreased substantially after only $3 \mathrm{~d}$ of vase life, to $60 \%$ to $70 \%$ of the day 0 average (Fig. $1 \mathrm{~A})$. By day 5 , the latter racemes experienced almost complete abscission (discussed later), and by day 10 , contained $50 \%$ to $60 \%$ of their original fresh weight, with a tendency for increased fresh weight loss with increasing duration of CEPA exposure.

Racemes previously treated with 1-MCP but not CEPA did not express observable fresh weight loss below the day 0 average until $6 \mathrm{~d}$, or $1 \mathrm{~d}$ later than the counterpart treatment without 1-MCP (Fig. 1A and B). By day 10, the 1-MCP-treated (non-CEPA) racemes had retained an average of $76 \%$ of their original fresh weight, or $7 \%$ more than in the non-1-MCP, non-CEPA controls. However, there were similar rates of fresh weight declination in the latter treatments during the last half of vase life. CEPA accelerated fresh weight loss from racemes treated with $1-\mathrm{MCP}$, but did so $2 \mathrm{~d}$ later than without 1-MCP (day 5 vs. day 3, respectively). Also, at days 5 and 10 of vase life, fresh weight retention with 1-MCP + CEPA averaged, respectively, $\approx 18 \%$ and $7 \%$ higher than it did in racemes that were exposed to CEPA but not 1-MCP.

Three days after harvest, there were $80 \%$ to $95 \%$ reductions in the retention of mature (fully opened) flowers (flower retention) initially present at harvest (e.g., increases in flower abscission) for the non-1-MCP-treated racemes that were exposed to CEPA in the vase solution (Fig. 2A). By day 5, these racemes were essentially devoid of flowers. Complete (100\%) abscission contributed less than $5 \%$ to fresh weight losses shown in Fig. 1. Loss in flower retention on non-1-MCPtreated racemes not held in CEPA was gradual but much less pronounced than in the presence of CEPA, with $60 \%$ of the original flowers still attached to the rachis on day 10. Increased flower retention was observed on racemes treated with 1-MCP (Fig. 2B) compared with those not treated with 1-MCP. Unlike the $87 \%$ to $60 \%$ flower retention on days 5 and 10 respectively in the non-1-MCP, non-CEPA treatment, the racemes that received 1-MCP and lacked CEPA had retained essentially all their flowers up to day $7,94 \%$ on day 8 , and $82 \%$ on day 10 . After postharvest 1-MCP treatment, CEPA accelerated abscission, particularly if applied longer than $2 \mathrm{~d}$. However, 1-MCP delayed CEPA-induced abscission by $2 \mathrm{~d}$ beyond that observed without 1-MCP treatment. At day 5, at least $40 \%$ of flowers were still retained by the 1-MCP-treated plus CEPA-treated racemes, although flower retention approached $0 \%$ by day 10 .

Apical meristematic growth during vase life, expressed as NNOF, was similar whether or not racemes received the postharvest 1MCP treatment, and provided that CEPA was omitted from the vase solution (Fig. 3A and $\mathrm{B}$ ). In both non-CEPA treatments, there were $\approx 18$ newly opened flowers at the apex by day 9 , and on average, fewer than one newly opened flower had abscised between days 9 and 10. Abscission of newly opened flowers was markedly increased after 2,4 , or $6 \mathrm{~d}$ of CEPA vase solution treatment. The NNOF on non-1-MCP-treated plus CEPA racemes averaged 2.7 on day 2, which 


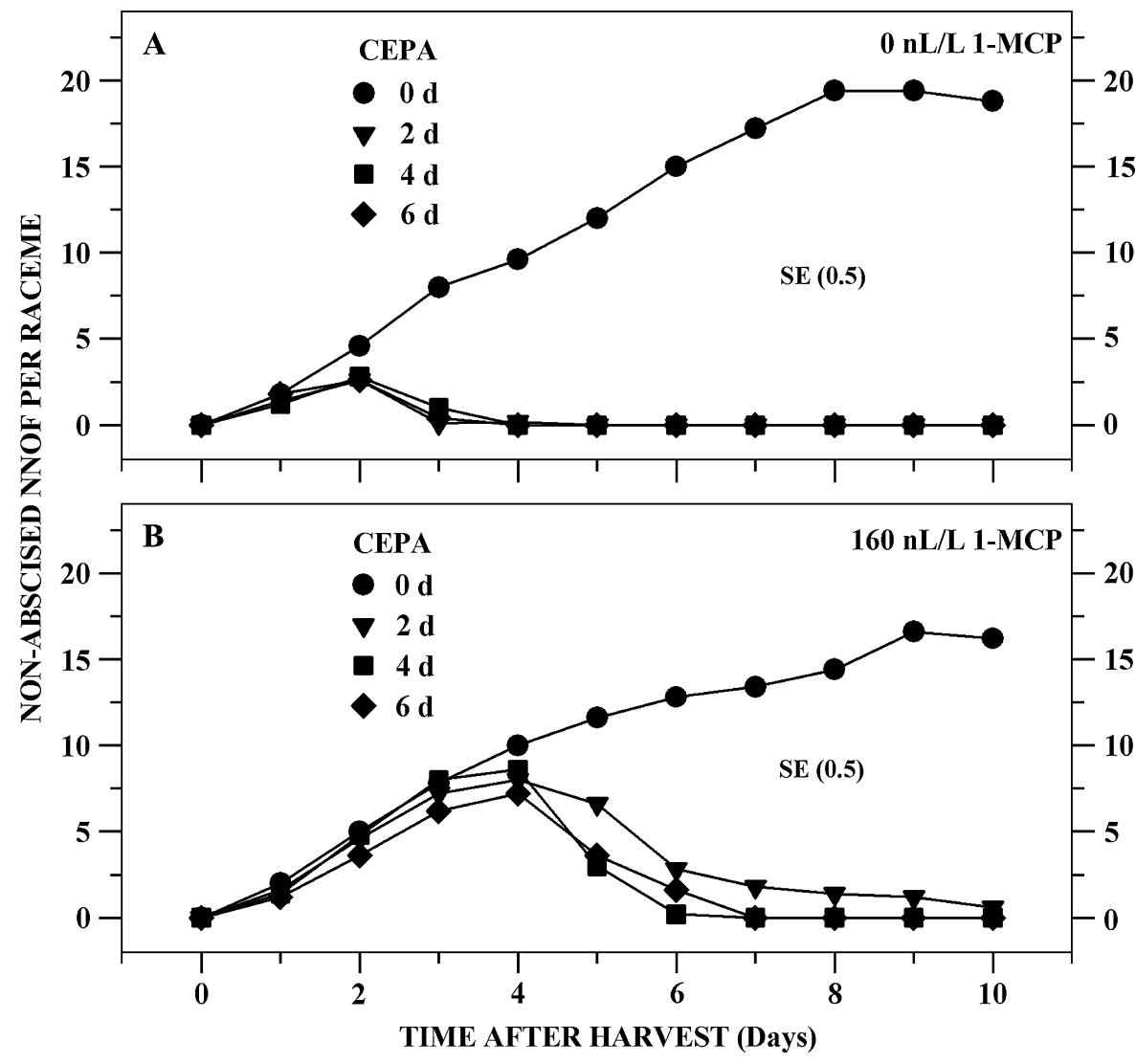

Fig. 3. (A, B) Number of intact newly opened flowers (NNOF) on cut 'Texas Sapphire' racemes without 1-methylcyclopropene (1-MCP) (A) or after postharvest 1-MCP treatment at $160 \mathrm{~nL} \cdot \mathrm{L}^{-1}(\mathbf{B})$, and further 2, chloroethyl phosphonic acid (CEPA) exposure $(50 \mu \mathrm{M})$ for $0,2,4$, or $6 \mathrm{~d}$ in the vase solution. Each point is the average of 10 single-raceme observations (combined data of two experiments). The $F$ tests for main effects of 1-MCP, CEPA, and days in the vase were significant at $P \leq 0.01$. The pooled $\mathrm{SE}$ is from the analysis of variance.

decreased to nil on day 3 and thereafter because of abscission and cessation of growth. Postharvest 1-MCP treatment largely counteracted the CEPA-related abscission of newly opened flowers through day 4 , when NNOF ranged from 7 to 8 per raceme irrespective of CEPA exposure of 2 to $6 \mathrm{~d}$. After day 4 , newly opened flowers abscised more slowly from the 1-MCP-treated racemes that received $2 \mathrm{~d}$ CEPA than they did from 1-MCP-treated racemes that received $4 \mathrm{~d}$ or 6 d CEPA. Essentially all newly opened flowers from 1-MCP and CEPA-treated racemes had abscised by day 10 .

The two-way interaction $(1-\mathrm{MCP} \times$ days in vase) is illustrated in Fig. 4 and considers the response variables of fresh weight, flower retention, and NNOF relevant to a postharvest environment wherein ethylene exposure cannot be predicted. The retention of fresh weight, preexisting (mature) flowers, and newly opening flowers was independent of 1-MCP for the first $2 \mathrm{~d}$ of vase life, despite $36 \mathrm{~h}$ prior exposure to 1-MCP. For fresh weight and NNOF (Fig. 4A and C), the majority of the 1-MCP effect began by 3 $\mathrm{d}$ after harvest and lasted for $\approx 3 \mathrm{~d}$ thereafter. By contrast, the 1-MCP main effect on flower retention (Fig. 4B) began at day 3 but persisted throughout the vase life observation period.
Raceme VVL was defined as the average number of days (after harvest) required for $\geq 50 \%$ of mature flowers (open at harvest) to abscise or express withering. There was no $1-\mathrm{MCP} \times \mathrm{CEPA}$ interaction on VLL. The VLL of racemes harvested from Expts. 1 and 2 averaged $3.9 \mathrm{~d}$ for non-1-MCP-treated racemes and $5.7 \mathrm{~d}$ for 1-MCP-treated racemes, pooled across the four CEPA exposure times. The longest average VLL (7.2 d) was recorded for racemes treated with 1-MCP but not with CEPA (Fig. 5). However, when 1-MCP-treated racemes were later exposed to CEPA for 2, 4, or $6 \mathrm{~d}$, average VLL ranged from only 5.0 to $5.4 \mathrm{~d}$. With any duration of CEPA, postharvest treatment with 1-MCP extended raceme VLL by an average of about $2 \mathrm{~d}$ beyond that of non-1-MCP treatment. The CEPA main effect sum of squares was partitioned into single degree-of-freedom linear and quadratic orthogonal contrasts. The contrasts showed that CEPA shortened VLL both linearly and quadratically $(P \leq$ $0.0001)$. The quadratic effect indicated that 2 , 4 , or $6 \mathrm{~d}$ of CEPA shortened VLL by similar amounts $(\approx 2 \mathrm{~d})$ below the VLL obtained with no CEPA, which is, in turn, broadly consistent with the findings in Figs. 1 through 3.

Flower electrolyte leakage (Expt. 3). One day after harvest, the overall RLR for the upper (younger) mature flowers that were expanded at harvest was 0.094 , whereas the overall RLR for the lower (older) mature flowers (expanded at harvest) was 0.240 (Fig. 6 ). This 2.5 -fold difference reflected the more developmentally advanced state of lower mature flowers. Higher percentage flower retention under these conditions (1 h CEPA) was obtained compared with extended CEPA duration (Fig. 2), because, irrespective of postharvest 1-MCP treatment and flower position, $\approx 80 \%$ of mature flowers were still on the rachis by day 6 ( $1 \mathrm{~h}$ CEPA, data not shown). Any abscised flowers were excluded from leakage measurements. Separate ANOVAS for upper and lower mature flowers revealed no significant main effects of 1-MCP $\left(0 \mathrm{~nL} \cdot \mathrm{L}^{-1}\right.$ or $\left.160 \mathrm{~nL} \cdot \mathrm{L}^{-1}\right)$ or CEPA $(0 \mu \mathrm{M}$ or $50 \mu \mathrm{M}, 1 \mathrm{~h})$ on RLR. One day after harvest, RLR differed little between upper and lower mature flower positions, and there were no observable effects of $1-\mathrm{MCP}$ or CEPA treatments, which had just ended at this time. The day main effect was highly significant at both flower positions $(P \leq$ 0.0001). For the upper mature flowers, RLR increased by an average of 0.075 between $1 \mathrm{~d}$ and $6 \mathrm{~d}$ after harvest (Fig. 6A and B). Average RLR of the more developmentally advanced lower mature flowers increased more conspicuously, by 0.356 , between $1 \mathrm{~d}$ and $6 \mathrm{~d}$ after harvest (Fig. 6C and D).

The 1 -MCP $\times$ CEPA and $1-\mathrm{MCP} \times \mathrm{CEPA}$ $\times$ days in vase interactions on RLR of the upper mature flowers were highly significant $(P \leq 0.01)$. Without CEPA, the 5-d increases in upper flower RLR were comparatively small and partially mitigated by $1-\mathrm{MCP}$ treatment (Fig. 6A; 0.043 vs. 0.094 increases for 1-MCP-treated and non-1-MCP-treated racemes, respectively). With CEPA, however, the 5-d increases in RLR of upper flowers from 1-MCP-treated racemes was 0.138 compared with a smaller RLR increase of 0.026 in upper flowers from racemes not treated with 1-MCP (Fig. 6B).

A similar pattern of RLR increase during vase life was observed for the lower mature flowers. At this flower position, the $1-\mathrm{MCP} \times$ days in vase interaction was significant $(P \leq$ $0.05)$, although the 1 -MCP $\times$ CEPA interaction did not reach statistical significance $(P=$ 0.1022 ) with the limited number of replications. Without CEPA, lower flower RLR rose sharply by day 6 and was similar with or without 1-MCP treatment (Fig. 6C). If the racemes had received $1 \mathrm{~h}$ CEPA in the vase solution after 1-MCP treatment, there was a 12-fold increase in RLR from days 1 to 6 of vase life (0.045-0.526) (Fig. 6 D). With no $1-\mathrm{MCP}$ treatment before the $1 \mathrm{~h}$ CEPA, there was less than a fourfold increase in RLR from days 1 to $6(0.075-0.274)$.

\section{Discussion}

The VLL of cut $L$. havardii reported in the current study $(\approx 3-7 \mathrm{~d}$, depending on postharvest treatment) is similar to a limited VLL reported for a number of other cut indeterminate inflorescences (Celikel and Reid, 

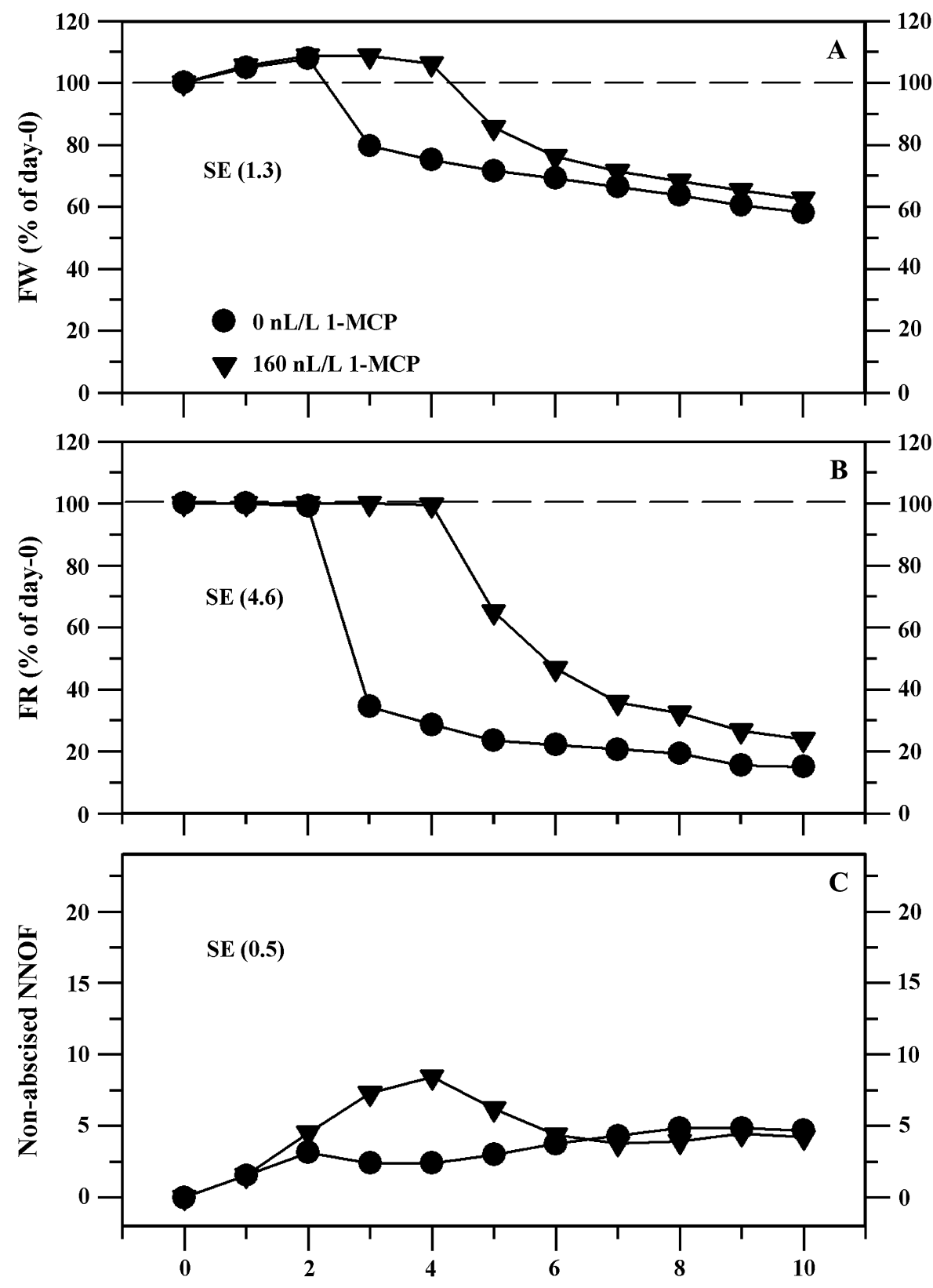

TIME AFTER HARVEST (Days)

Fig. 4. (A-C) Relative fresh weight (FW) (A), relative flower retention (FR) (B), and absolute number of nonabscised newly opened flowers (NNOF) (C) of cut 'Texas Sapphire' racemes without 1-methylcyclopropene (1-MCP) or after postharvest $1-\mathrm{MCP}$ treatment at $160 \mathrm{~nL} \cdot \mathrm{L}^{-1}$. Each point is the average of 10 single-raceme observations. For FW and FR, data are expressed as a percentage of harvest (day 0), whereas NNOF is an absolute number. For FW, FR, and NNOF, data are pooled across 2 , chloroethyl phosphonic acid (CEPA) exposure $(50 \mu \mathrm{M})$ for $0,2,4$, or $6 \mathrm{~d}$ in the vase solution. The $F$ tests for main effects of 1-MCP, CEPA, and days in the vase were significant at $P \leq 0.01$. The pooled SE is from the analysis of variance.

2002; Cho et al., 2001; Han, 1998, 2003; Ichimura et al., 2000; Serek et al., 1994). Therefore, continued efforts to extend VLL of the newly introduced $L$. havardii could increase consumer demand and incentives for commercialization. Based on our findings, $1-\mathrm{MCP}$ should be considered in those efforts.

The current findings support the concept that inflorescence fresh weight change is an important process during initiation of cut flower senescence (Borochov and Woodson, 1989; Van Doorn, 1997), and as such, is an important determinant of VLL. Waithaka et al. (2001) and Celikel and Reid (2002) reported a close temporal relationship between termination of tuberose and stock vase life, and time needed for inflorescence fresh weight to drop below the initial value. We found a similar relationship when comparing data on fresh weight declination (Fig. 1) with VLL (Fig. 5) for 'Texas Sapphire' receiving any CEPA $\times 1-\mathrm{MCP}$ combination.

Desiccation during vase life of cut 'Texas Sapphire' racemes is confined to mature flowers originally present at time of harvest, which experience up to an $\approx 70 \%$ loss in fresh weight and express withering by $6 \mathrm{~d}$ of vase life (Picchioni et al., 2002). Growth of the newly opening flowers partially counteracts total raceme fresh weight declines (Fig. 1). However, there is an overriding influence of net water loss from mature flowers on total raceme fresh weight in that the loss exceeds net apical water gain by a factor of approximately three (Picchioni et al., 2007). In cut carnations, only a $25 \%$ reduction in stem fresh weight corresponded to a turgor pressure of $0 \mathrm{mPa}$ and a visual expression of petal wilting (Mayak, 1987). These findings suggest that water deficits in the mature flowers of cut 'Texas Sapphire' are a critical factor in VLL.

For a given combination of the two 1 -MCP treatments and 2, 4, or $6 \mathrm{~d}$ of CEPA treatment, the major losses in raceme fresh weight, flower retention, and NNOF occurred on the same day of vase life (Figs. 1-3). Postharvest 1-MCP treatment delayed the CEPA-induced raceme desiccation, mature flower drop, and newly opened flower drop by $2 \mathrm{~d}$. Although $50 \mu \mathrm{M}$ is a relatively low CEPA concentration for cut flower studies (Chanasut et al., 2003), it greatly accelerated declines in fresh weight and flower retention of 'Texas Sapphire', which confirms high ethylene sensitivity of this inflorescence (Sankhla et al., 1999, 2001; Vasquez, 1998). Thus, 1-MCP appears to be of particular value in counteracting deleterious effects of exogenous ethylene in 'Texas Sapphire' postharvest environments.

Although the protective effects of 1-MCP were most pronounced in the presence of CEPA, data also suggest that 1-MCP at least partially suppressed action of biosynthesized ethylene. That is, the relatively subtle effect of 1-MCP without CEPA still afforded a 1 -d delay in fresh weight declination below the harvest average (Fig. 1), a 4-d delay in observable abscission of mature flowers (Fig. 2), and a 2-d extension of VLL (Fig. 5).

The $1-\mathrm{MCP} \times$ days in vase interaction, graphically illustrated across CEPA exposure time (Fig. 4), shows the beneficial effects of using 1-MCP on 'Texas Sapphire' racemes under postharvest environments in which the presence of exogenous ethylene or concentration of exogenous ethylene are not known. This situation may arise while storing, transporting, or retailing cut flowers Under these ethephon-"masked" conditions, the protective effect of 1-MCP persisted for $3 \mathrm{~d}$ or longer, depending on raceme response variable.

Enhanced raceme desiccation, mature flower drop, and newly opened flower drop began at vase life day 5 in the 1-MCP + CEPA treatments (Figs. 1-3). This may indicate that 1-MCP-treated racemes regained sensitivity to ethylene, as has been proposed in other cut flower studies (Cameron and Reid, 2001; Macnish et al., 2000). The transitory influence of $1-\mathrm{MCP}$ is thought to result from the synthesis of new ethylene receptor molecules not present at the time of 1-MCP treatment (Sisler and Serek, 1997, 2003). Accordingly, our findings suggest that 


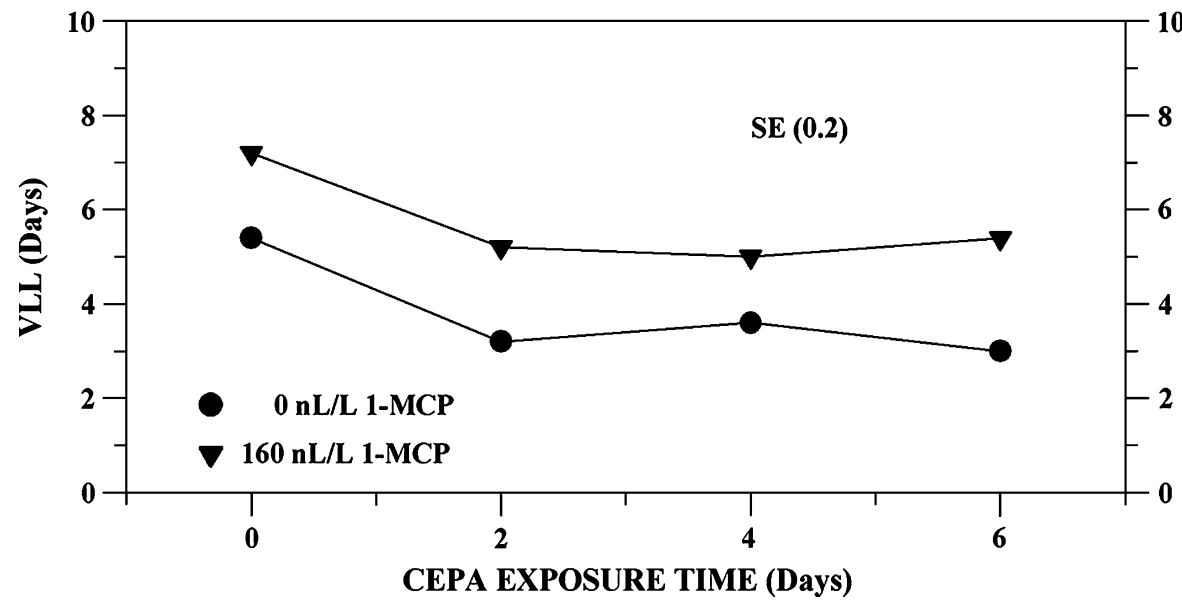

Fig. 5. Vase life longevity (VLL) in days of cut 'Texas Sapphire' racemes without 1-methylcyclopropene (1-MCP) or after postharvest 1-MCP treatment at $160 \mathrm{~nL} \cdot \mathrm{L}^{-1}$, averaged across the four 2 , chloroethyl phosphonic acid (CEPA) $50 \mu \mathrm{M}$ exposure times $(0,2,4$, or $6 \mathrm{~d})$ in the vase solution. Each point represents a discrete value and determined as described in the text. The $F$ tests for main effects of 1 -MCP, CEPA, and days in the vase were significant at $P \leq 0.01$. The pooled SE is from the analysis of variance.
O $\mu$ M CEPA
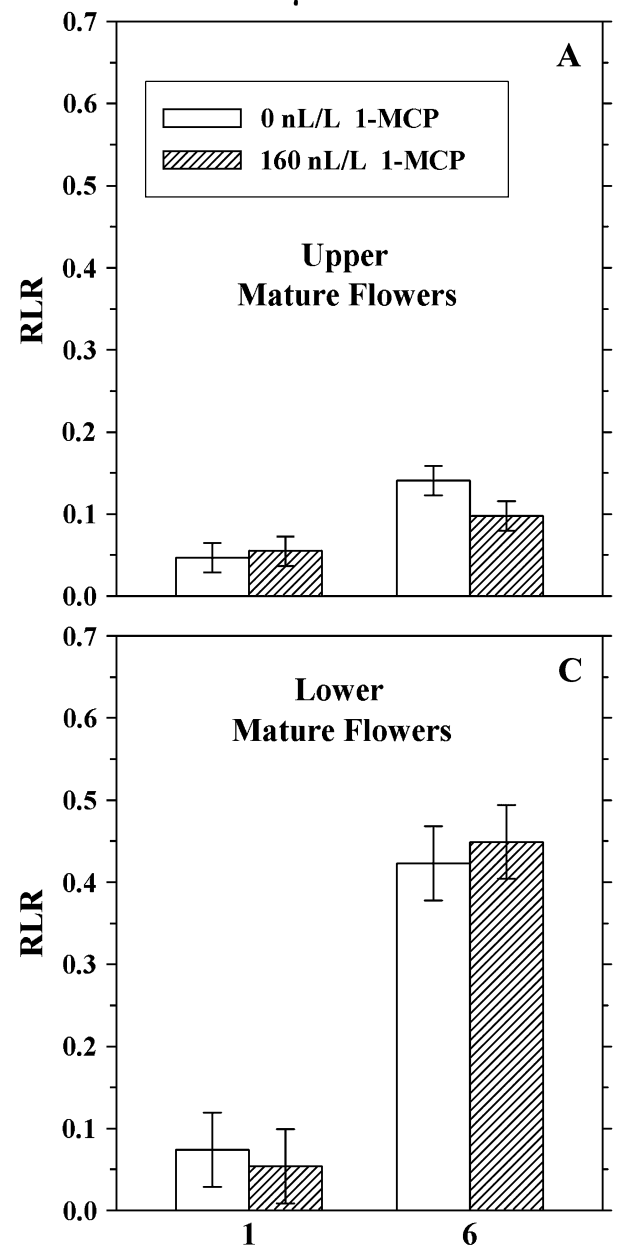
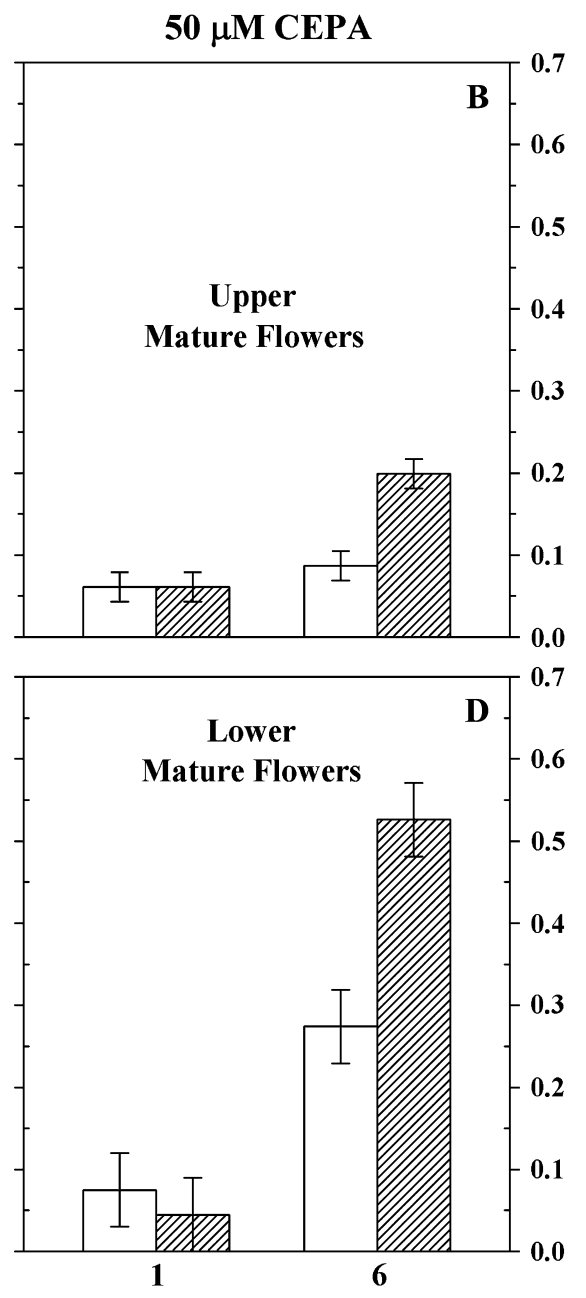

TIME AFTER HARVEST (Days)

Fig. 6. (A-D) Relative leakage ratio (RLR) of mature flowers (minus pedicels) on cut 'Texas Sapphire' racemes with or without postharvest 1-methylcyclopropene (1-MCP) treatment at $160 \mathrm{~nL} \cdot \mathrm{L}^{-1}$, no 2 , chloroethyl phosphonic acid (CEPA) (A, C), or exposed to $50 \mu \mathrm{M}$ CEPA in the vase solution for $1 \mathrm{~h}(\mathbf{B}$, D). All flowers were fully expanded at time of harvest (day 0) with the upper flowers $(\mathbf{A}, \mathbf{B})$ on the upper half of the rachis, and the lower flowers $(\mathbf{C}, \mathbf{D})$ on the lower half of the rachis. Any abscised flowers were excluded. Each point is the average of five double-raceme observations \pm SE. The $F$ test for main effect of days was significant for both upper and lower flower analyses of variance $(P \leq 0.0001)$. once 1-MCP bound to ethylene receptors, its inhibition of ethylene action on raceme water balance and flower retention persisted for $\approx 2 \mathrm{~d}$. This hypothesis is supported by a CEPA duration-dependent effect at day 5 (Figs. 1B, $2 \mathrm{~B}$, and $3 \mathrm{~B}$ ), and by preliminary results we have obtained with multiple 1-MCP applications to cut 'Texas Sapphire' made every $2 \mathrm{~d}$ between $0 \mathrm{~d}$ and $6 \mathrm{~d}$ of total vase life (unpublished data).

The marginally smaller 5-d increase in RLR of upper mature flowers from racemes receiving postharvest 1-MCP but no CEPA treatment compared with flowers from racemes receiving neither 1-MCP nor CEPA (day 6 in Fig. 6A) is consistent with senescence-delaying effects of 1-MCP. Consequently, the enhanced 5-d RLR increase in both upper and lower mature flowers from 1-MCP and CEPA-treated racemes compared with racemes receiving CEPA but no $1-\mathrm{MCP}$ was somewhat unexpected (day 6 in Figs. 6B and D). The EC after freezing in liquid $\mathrm{N}_{2}$ averaged $20 \%$ higher in the $+1-\mathrm{MCP} /+\mathrm{CEPA}$ treatment than in the CEPA-only treatment (EC at $6 \mathrm{~d}$ vase life, normalized to a perflower basis to account for $\approx 20 \%$ abscission of mature flowers; data not shown). In similar experimental conditions using silver thiosulfate in place of 1-MCP and followed by continuous $50 \mu \mathrm{M}$ CEPA in the vase solution, we observed that total export of $\mathrm{N}, \mathrm{P}$, and $\mathrm{K}$ from senescing, mature 'Texas Sapphire' flowers was $33 \%$ to $90 \%$ less than total N, P, and K export from mature flowers on racemes receiving only CEPA (unpublished data). Thus, higher electrolyte leakage in flowers from the $+1-\mathrm{MCP} /+\mathrm{CEPA}$ treatment may be attributable to a greater amount of diffusible electrolytes present in the tissue. The greater amount of diffusible electrolytes may, in turn, be associated with delayed development (delayed electrolyte export) from mature flowers by $1-\mathrm{MCP}$. More research is needed to elucidate the physiological basis of interaction between ethylene action inhibitors, exogenous ethylene, cell membranes, and phloem export from mature flowers to apical tissues of the cut L. havardii inflorescence.

The findings from the current study counter prevailing concepts of postharvest biology of cut flowers in general and of L. havardii in particular. First, solute leakage determined at a given stage of vase life may be of questionable value in assessing senescence-related cell permeability change, as has been typically inferred in the floriculture senescence literature (Borochov and Woodson, 1989; Halevy and Mayak, 1979). Senescing petals of cut 'Texas Sapphire' racemes take on a capacity to export lowmolecular weight solutes and electrolytes in response to increasing metabolic demands of the floral apical meristem (Picchioni et al., 2007). The increase in RLR appears to reflect this developmentally regulated function as a source organ rather than only an increase in permeability per se. Only recently have mineral-exporting traits of senescing petals received quantitative study (Bieleski, 2000; Verlinden, 2004). 
Mature flower abscission is regarded as the major ethylene-regulated process determining the end of vase life for cut $L$. havardii racemes (Sankhla et al., 2001). However, total inflorescence fresh weight and the opening and retention of flowers are considered to be important postharvest quality attributes of other indeterminate inflorescences (Chanasut et al., 2003; Han, 1998; Ichimura and Hisamatsu, 1999). In 'Texas Sapphire', the latter characteristics responded in markedly similar fashion, as did mature flower retention. Fresh weight and flower opening should therefore be considered in developing commercially applicable longevity criteria for this new specialty cut flower.

\section{Literature Cited}

Bieleski, R.L. 2000. The bigger picture: Phloem seen through horticultural eyes. Aust. J. Plant Physiol. 27:615-624.

Borochov, A. and W.R. Woodson. 1989. Physiology and biochemistry of flower petal senescence. Hort. Rev. (Amer. Soc. Hort. Sci.) 11:15-43.

Cameron, A.C. and M.S. Reid. 2001. 1-MCP blocks ethylene-induced petal abscission of Pelargonium peltatum but the effect is transient. Postharvest Biol. Technol. 22:169-177.

Celikel, F.G. and M.S. Reid. 2002. Postharvest handling of stock (Matthiola incana). HortScience 37:144-147.

Chanasut, U., H.J. Rogers, M.K. Leverentz, G. Griffiths, B. Thomas, C. Wagstaff, and A.D. Stead. 2003. Increasing flower longevity in Alstromeria. Postharvest Biol. Technol. 29:325-333.

Cho, M., F. Celikel, L. Dodge, and M.S. Reid. 2001. Sucrose enhances the postharvest quality of cut flowers of Eustoma grandiflorum (Raf.) Shinn. Acta Hort. 543:305-310.

Davis, T.D., S.W. George, W.A. Mackay, and J.M. Parsons. 1994. Development of Texas bluebonnets into floricultural crops. HortScience 29:1110, 1121.

Dracup, M. and E.J.M. Kirby. 1996. Lupin development guide. University of Western Australia Press, Netherlands.

Halevy, A.H. and S. Mayak. 1979. Senescence and postharvest physiology of cut flowers. Hort. Rev. (Amer. Soc. Hort. Sci.) 1:204-236.
Han, S.S. 1998. Postharvest handling of cut Heuchera sanguinea Engelm. flowers: Effects of sucrose and silver thiosulfate. HortScience 33:731-733.

Han, S.S. 2003. Role of sugar in the vase solution on postharvest flower and leaf quality of Oriental lily 'Stargazer'. HortScience 38: 412-416.

Ichimura, K. and T. Hisamatsu. 1999. Effects of continuous treatment with sucrose on the vase life, soluble carbohydrate concentrations, and ethylene production of cut snapdragon flowers. J. Jpn. Soc. Hort. Sci. 68:61-66.

Ichimura, K., K. Kohata, and R. Goto. 2000. Soluble carbohydrates in Delphinium and their influence on sepal abscission in cut flowers. Physiol. Plant. 108:307-313.

Mackay, W.A. and T.D. Davis. 1998. 'Texas Sapphire' and 'Texas Ice' long-stem bluebonnets (Lupinus havardii). HortScience 33:348-349.

Mackay, W.A., T.D. Davis, and D. Sankhla. 1995. Influence of scarification and temperature treatments on seed germination of Lupinus havardii. Seed Sci. Technol. 23:815-821.

Mackay, W.A., D. Sankhla, T.D. Davis, and N. Sankhla. 1999. Studies on postharvest performance of cut racemes of Big Bend bluebonnet. HortScience 34:503 (abstr.).

Macnish, A.J., D.H. Simons, D.C. Joyce, J.D. Faragher, and P.J. Hofman. 2000. Responses of native Australian cut flowers to treatment with 1-methylcyclopropene and ethylene. HortScience 35:254-255.

Mayak, S. 1987. Senescence of cut flowers. HortScience 22:863-865.

Newman, J.P., L.L. Dodge, and M.S. Reid.. 1998. Evaluation of ethylene inhibitors for postharvest treatment of Gypsophila paniculata L. HortTechnology 8:58-63.

Picchioni, G.A., M. Valenzuela-Vázquez, and L.W. Murray. 2002. Calcium and 1- methylcyclopropene delay desiccation of Lupinus havardii cut racemes. HortScience 37:122-125.

Picchioni, G.A., W.A. Mackay, and M. ValenzuelaVázquez. 2007. Correlative supply and demand functions in Lupinus havardii: A forgotten side of cut flower physiology? J. Amer. Soc. Hort. Sci (In Press).

Sankhla, N., W.A. Mackay, and T.D. Davis. 1999. Effect of EthylBloc on postharvest performance and ethylene production of cut racemes of Big Bend bluebonnet. Proc. Plant Growth Regulat. Soc. Amer. 26:190-192.

Sankhla, N., W.A. Mackay, and T.D. Davis. 2001 Extension of vaselife and prevention of ethyleneinduced flower shattering in Lupinus havardi by 1-methylcyclopropene. Acta Hort. 543: $75-78$

SAS Institute. 1990. SAS user's guide: Statistics, version 6. 4th ed. SAS Institute, Cary, N.C.

Serek, M., R.B. Jones, and M.S. Reid. 1994. Role of ethylene in opening and senescence of Gladiolus flowers. J. Amer. Soc. Hort. Sci. 119:1014-1019.

Serek, M., E.C. Sisler, and M.S. Reid. 1995a. Effects of 1-MCP on the vase life and ethylene response of cut flowers. Plant Growth Regul. 16:93-97.

Serek, M., E.C. Sisler, T. Tirosh, and S. Mayak. 1995b. 1-Methylcyclopropene prevents bud, flower, and leaf abscission of Geraldton waxflower. HortScience 30:1310.

Sisler, E.C., E. Dupille, and M. Serek. 1996. Effect of 1-methylcyclopropene and methylenecyclopropane on ethylene binding and ethylene action on cut carnations. Plant Growth Regul. 18:79-86.

Sisler, E.C. and M. Serek. 1997. Inhibitors of ethylene responses in plants at the receptor level: Recent developments. Physiol. Plant. 100:577-582

Sisler, E.C. and M. Serek. 2003. Compounds interacting with the ethylene receptor in plants. Plant Biol. 5:473-480.

Van Doorn, W.G. 1997. Water relations of cut flowers. Hort. Rev. (Amer. Soc. Hort. Sci.) 18:1-85.

Vasquez, K.L. 1998. Ethylene production and sensitivity in Lupinus havardii, Big Bend bluebonnet. N.M. State Univ., Las Cruces, master's thesis.

Verlinden, S. 2004. Changes in mineral nutrient concentrations in petunia corollas during development and senescence. HortScience 38:71-74.

Waithaka, K., M.S. Reid, and L.L. Dodge. 2001. Cold storage and flower keeping quality of cut tuberose (Polianthes tuberosa L.). J. Hort. Sci. Biotechnol. 76:271-275.

Young, K. 1997. Hot hues. Floral Mgt. 14:41-45.

Young, K. 1999. Hands on: Ready-to-use ideas for better business. Floral Mgt. 15:11-13. 